\title{
Influence of Post Emergence Application of Glyphosate on Weed Control Efficiency and Yield of Transgenic Maize
}

\author{
Duraisamy Ravisankar ${ }^{*}$, Chinnagoundar Chinnusamy, Purushothaman Muthukrishnan \\ Department of Agronomy, Tamil Nadu Agricultural University, Coimbatore, India. \\ Email: ${ }^{*}$ ravi.agri@gmail.com
}

Received May $26^{\text {th }}, 2013$; revised June $27^{\text {th }}, 2013$; accepted July $16^{\text {th }}, 2013$

Copyright (C) 2013 Duraisamy Ravisankar et al. This is an open access article distributed under the Creative Commons Attribution License, which permits unrestricted use, distribution, and reproduction in any medium, provided the original work is properly cited.

\begin{abstract}
Field experiment was conducted during kharif 2009 and rabi 2009-2010 at Tamil Nadu Agricultural University, Coimbatore to evaluate the weed control efficiency and yield potential of glyphosate resistant transgenic maize. Treatments consisted of two transgenic maize hybrids named Hishell and $900 \mathrm{M}$ gold with application of glyphosate as post emergence at 900, 1800 and $3600 \mathrm{~g}$ a.e/hathese were compared with non-transgenic counterpart maize hybrids with application of atrazine as pre-emergence at $0.5 \mathrm{~kg} / \mathrm{ha}$ followed by one hand weeding at 40 Days After Sowing along with need based insect control practices. Post emergence application of glyphosate at 900,1800 and $3600 \mathrm{~g}$ a.e/ha in transgenic maize hybrids was recorded with lower weed density and higher weed control efficiency compared to other treatments. Higher grain yield was recorded with post emergence application of glyphosate at $1800 \mathrm{~g}$ a.e/ha in transgenic hybrid $900 \mathrm{M}$ Gold and $3600 \mathrm{~g}$ a.e/ha in transgenic hybrid Hishell during kharif 2009 and rabi 2009-2010 seasons, respectively.
\end{abstract}

Keywords: Glyphosate Tolerant Maize; Weed Control Efficiency; Yield

\section{Introduction}

Weed infestation in maize is one of the key factors responsible for the lower productivity and poor quality of produce. Reduction in grain yield is ranged from 33 to 50 per cent or even more depending upon the intensity and nature of the weed flora [1]. The traditional method of manual and mechanical weeding is quite effective, but arduous, time consuming and highly costly. Under such situation, chemical weed control is a better option to conventional methods and use of herbicides forms an integral part of the modern crop production. In the last few decades different herbicides were used alone or in combination to eliminate the weeds but their efficiencies differ because of their narrow spectrum of weed control.

In the recent years, the introduction of herbicide tolerant crops has transformed the way of chemical weed management method. Herbicide tolerant crops and their weed management systems allowed the use of broadspectrum post emergence herbicides, which have reduced environmental impact. These systems may reduce the use

${ }^{*}$ Corresponding author. of soil applied residual herbicides and consequently reduce the potential for these herbicides to leach into groundwater [2]. Transgenic stacked hybrid maize (MON $89034 \times$ NK 603) was developed for preventing yield losses of maize crop due to pests and weeds and to improve productivity. The stacked maize crop having both insect protection and herbicide tolerant traits will provide protection to the crop from target pests and also provide tolerance to glyphosate herbicide. MON 89034 is second generation Bt corn technology effective against lepidopteron insect pests with a unique and innovative dual mode of action. NK 603 is the glyphosate tolerant technology for the effective weed management system. The plants become tolerant to the herbicide while weed flora are suppressed after application of herbicide. These efficacious systems allow post emergence use of glyphosate for total weed management in glyphosate tolerant transgenic maize. In view of the importance of chemical weed control in herbicide tolerant transgenic maize, field experiments were conducted at Tamil Nadu Agricultural University, Coimbatore to evaluate the weed control efficiency and yield of transgenic stacked maize hybrids. 


\section{Material and Methods}

\subsection{Experimental Site and Initial Soil Characteristics}

The research was conducted with glyphosate resistant maize hybrids during kharif 2009 and rabi 2009-2010 seasons at experimental site of Tamil Nadu Agricultural University, Coimbatore, Tamil Nadu, India. The experimental site is situated in Western Agro climatic zone of Tamil Nadu with $11^{\circ} \mathrm{N}$ longitude, $77^{\circ} \mathrm{E}$ latitude and at an altitude of $426.7 \mathrm{~m}$ above mean sea level and the farm receives the normal annual total rainfall of $674.2 \mathrm{~mm}$ in 45.8 rainy days. The soil of the experimental field was sandy clay loam in texture with low available nitrogen $(165 \mathrm{~kg} / \mathrm{ha})$, medium available phosphorus $(11.2 \mathrm{~kg} / \mathrm{ha})$ and high available potassium $(585 \mathrm{~kg} / \mathrm{ha})$.

\subsection{Experimental Design, Selection of Cultivar and Sowing}

The experiment was laid out in randomized complete block design (RBD) with fourteen treatments and replicated thrice. The gross plot size adopted was $18.0 \mathrm{Sq}$. meter $(3.6 \mathrm{~m} \times 5.0 \mathrm{~m})$. Two herbicide tolerant transgenic maize test hybrids named transgenic Hishell and Transgenic $900 \mathrm{M}$ Gold were used for the experiment. The seeds were dibbled at a depth of $4 \mathrm{~cm}$ and adopting a spacing of $60 \mathrm{~cm}$ between rows and $25 \mathrm{~cm}$ between the plants.

\subsection{Treatment Details}

Treatments consisted of post emergence application of glyphosate at 900, 1800 and $3600 \mathrm{~g}$ a.e/haat 2 - 4 leaf stage of weeds (approximately 25 Days After Sowing of transgenic maize hybrids) in transgenic maize hybrids. In non-transgenic maize hybrids viz., Hishell, 900 M Gold, COHM 5 (local test hybrid) and Proagro (national test hybrid) with pre-emergence application of atrazine 0.5 $\mathrm{kg} / \mathrm{ha}$ at 3 Days After Sowing (DAS) followed byone hand weeding (HW) at 40 DAS along with insect control was done by whorl application of carbofuran at $1.0 \mathrm{~kg}$ a.i/ha at $20 \mathrm{DAS}$.

\subsection{Observations}

\subsubsection{Weed Density}

The weed count was recorded species wise using $0.5 \mathrm{~m} \times$ $0.5 \mathrm{~m}$ quadrat from four randomly fixed places in each plot and the weeds falling within the frames of the quadrat were counted and the mean values were expressed in number $\mathrm{m}^{-2}$. The densities of grasses, sedges and broad leaved weeds and the total weeds were recorded at 10 and 25 days after first and second spraying of glyphosate and expressed in number $\mathrm{m}^{-2}$.

\subsubsection{Weed Dry Weight}

The weeds falling within the frames of the quadrat were collected, categorised into grasses, sedges and broadleaved weeds, shade dried and later dried in hot-air oven at $80^{\circ} \mathrm{C}$ for $72 \mathrm{hrs}$. The dry weight of grasses, sedges and broadleaved weeds were recorded separately at 10 and 25 days after first and second spraying of glyphosate and expressed in $\mathrm{kg} / \mathrm{ha}$.

\subsubsection{Weed Control Efficiency}

Weed control efficiency (WCE) was calculated as per the procedure [3].

$$
\mathrm{WCE} \%=\frac{\mathrm{WD}_{\mathrm{c}}-\mathrm{WD}_{\mathrm{t}}}{\mathrm{WD}_{\mathrm{c}}} \times 100
$$

where, WCE - weed control efficiency (percent); $\mathrm{WD}_{\mathrm{c}}-$ weed biomass $\left(\mathrm{g} \cdot \mathrm{m}^{-2}\right)$ in control plot; $\mathrm{WD}_{\mathrm{t}}$-weed biomass $\left(\mathrm{g} \cdot \mathrm{m}^{-2}\right)$ in treated plot.

\subsection{Statistical Analysis}

The data were statistically analysed following the procedure [4] for randomised block design. The data pertaining to weeds were transformed to square root scale of $\sqrt{(X+2)}$. Whenever significant difference existed, critical difference was constructed at five per cent probability level. Such of those treatments where the difference are not significant are denoted as NS.

\section{Results and Discussion}

\subsection{Weed Flora}

The results of the experiment revealed that the broad leaved weeds dominated over grasses and sedge. Among the individual weed species, Trianthema portulacastrum, Cleome gynandra, Digera arvensis, Datura stramonium, Cynodon dactylon, Dactyloctenium aegyptium, Commelina bengalinsis and Cyperus rotundus were predominant in maize field during both the seasons. Among broad leaved weeds, Trianthema portulacastrumwas the dominant one during both the seasons. This might be due to the smothering effect of broad leaved weeds on monocots. The leaf area of the weed was more favourable for interception of brighter solar radiation. Similar studies reported that maize crop infested with major broad leaved weeds were Trianthema pórtulacastrum, Digera arvensis, Phyllanthus niniri, Amaranthus viridis. Among the grassy weeds Cynodon dactylon and Dactyloctenium aegyptium had dominated. Cyperus rotundus was the major sedge weed [5].

\subsection{Total Weed Density and Dry Weight}

Significant variation in total weed density was observed 
among the weed control treatments. During kharif 2009, significantly lesser and comparable density of total weeds was achieved with pre-emergence application of atrazine at $0.5 \mathrm{~kg} / \mathrm{ha}$ followed by HW under non-transgenic Hishell $\left(\mathrm{T}_{7}\right)$ and Proagro $\left(\mathrm{T}_{13}\right)$. These were comparable with non-transgenic $900 \mathrm{M}$ Gold and CoHM 5 maize hybrids with same treatment at 20 DAS. Relatively, higher densities were observed under unweeded checks and transgenic maize without application of glyphosate. Whereas, at 40 DAS, significantly lesser and comparable density of weeds were observed under transgenic $900 \mathrm{M}$ Gold maize hybrid with post emergence application of glyphosate at $3600 \mathrm{~g}$ a.e/ha $\left(\mathrm{T}_{6}\right)$. During rabi 2009-2010, lesser weed density was recorded under non-transgenic Hishell maize hybrid applied with pre-emergence atrazine at 0.5 $\mathrm{kg} \cdot \mathrm{ha}^{-1}$ followed by HW $\left(\mathrm{T}_{7}\right)$ at 20 DAS. This was comparable withsame treatment applied under non-transgenic 900 M Gold, Proagro and CoHM 5. Whereas at 40 DAS, with post emergence application of glyphosate at 1800 and $3600 \mathrm{~g}$ a.e/ha under transgenic Hishell and $900 \mathrm{M}$ Gold registered significantly lesser density of weeds. This was closely followed by POE glyphosate at $900 \mathrm{~g}$ a.e/ha under the same hybrids (Table 1).
Among the various rates of glyphosate, glyphosate at $1800 \mathrm{~g}$ a.e/ha in transgenic $900 \mathrm{M}$ Gold $\left(1.0 \mathrm{No}\right.$ 's $\left./ \mathrm{m}^{2}\right)$ and $3600 \mathrm{~g}$ a.e/ha in transgenic Hishell $\left(2.3 \mathrm{No}\right.$ 's $\left./ \mathrm{m}^{2}\right)$ recorded lesser total weed density during kharif and rabi seasons, respectively at 40 DAS. Glyphosate at $900 \mathrm{~g}$ a.e/hagave lesser control when compared to higher doses, also it failed to control weeds after 60 DAS. Lower dose of glyphosate was not effective in controlling Cyperus rotundus and some broad leaved weeds like Commelina benghalensis and Cyanotis axillaris. Glyphosate provides marginal or no control of weeds such as Cynodon dactylon, Solanum carolinense and tropical Commelina benghalensis [6]. In non-transgenic maize hybrids, application of atrazine at $0.5 \mathrm{~kg} / \mathrm{ha}$ was proved as effective preemergence weed control option in maize. Atrazine effectively controlled majority of broad leaved and grassy weeds at earlier stages of maize growth. Application of atrazine at $0.5 \mathrm{~kg} / \mathrm{ha}$ as pre-emergence followed by inter cultivation at 35 DAS in maize significantly reduced the total weed density and weed dry weight [7].

Weed dry weight is the most important parameter to assess the weed competitiveness for the crop growth and productivity. Sparse weeds with high biomass might be

Table 1. Effect of weed management methods on total weed density in transgenic and non-transgenic maize.

\begin{tabular}{|c|c|c|c|c|}
\hline \multirow{3}{*}{ Treatments } & \multicolumn{4}{|c|}{ Total weed density $\left(\mathrm{No}^{\mathrm{m}} \mathrm{m}^{-2}\right.$ ) } \\
\hline & \multicolumn{2}{|c|}{ Kharif 2009} & \multicolumn{2}{|c|}{ Rabi 2009-2010 } \\
\hline & 40 DAS & 65 DAS & 40 DAS & 65 DAS \\
\hline $\mathrm{T}_{1}$-Transgenic Hishell POE glyphosate @ $900 \mathrm{~g} / \mathrm{ha}$ & $3.61(11.0)$ & $3.83(12.7)$ & $4.24(16.0)$ & $3.96(13.7)$ \\
\hline $\mathrm{T}_{2}$-Transgenic Hishell POE glyphosate @ $1800 \mathrm{~g} / \mathrm{ha}$ & $2.65(5.0)$ & $3.32(9.0)$ & $3.16(8.0)$ & $2.52(4.3)$ \\
\hline $\mathrm{T}_{3}$-Transgenic Hishell POE glyphosate @ 3600 g/ha & $2.00(2.0)$ & $2.45(4.0)$ & $2.08(2.3)$ & $2.00(2.0)$ \\
\hline $\mathrm{T}_{4}$-Transgenic 900 M Gold POE glyphosate @ $900 \mathrm{~g} / \mathrm{ha}$ & $3.79(12.3)$ & $4.47(18.0)$ & $4.40(17.3)$ & $3.87(13.0)$ \\
\hline $\mathrm{T}_{5}$-Transgenic $900 \mathrm{M}$ Gold POE glyphosate @ $1800 \mathrm{~g} / \mathrm{ha}$ & $1.73(1.0)$ & $3.31(9.0)$ & $3.00(7.0)$ & $2.71(5.3)$ \\
\hline $\mathrm{T}_{6}$-Transgenic 900 M Gold POE glyphosate @ 3600 g/ha & $1.73(1.0)$ & $2.38(3.7)$ & $2.16(2.7)$ & $1.73(1.0)$ \\
\hline $\mathrm{T}_{7}$-Hishell PE atrazine @ $0.5 \mathrm{~kg} / \mathrm{ha}+\mathrm{HW}+\mathrm{IC}$ & $8.02(62.3)$ & $5.03(23.4)$ & $7.30(51.3)$ & $5.10(24.0)$ \\
\hline $\mathrm{T}_{8}-$ Hishell No WC and no IC & $13.04(168.0)$ & $12.42(152.3)$ & $11.39(127.7)$ & $10.94(117.7)$ \\
\hline $\mathrm{T}_{9}$ —900 M Gold PE atrazine @ $0.5 \mathrm{~kg} / \mathrm{ha}+\mathrm{HW}+\mathrm{IC}$ & $7.66(56.7)$ & $5.10(24.0)$ & $7.28(51.0)$ & $5.26(25.7)$ \\
\hline $\mathrm{T}_{10}-900 \mathrm{M}$ Gold No WC and no IC & $13.29(174.7)$ & $12.40(151.7)$ & $11.82(137.7)$ & $10.68(112.0)$ \\
\hline $\mathrm{T}_{11}$ —Proagro PE atrazine $0.5 @ \mathrm{~kg} / \mathrm{ha}+\mathrm{HW}+\mathrm{IC}$ & $8.02(62.3)$ & $4.87(21.7)$ & $7.12(48.7)$ & $5.10(24.0)$ \\
\hline $\mathrm{T}_{12}$-Proagro 4640 No WC and no IC & $13.06(168.7)$ & $12.14(145.3)$ & $11.56(131.7)$ & $10.46(107.3)$ \\
\hline $\mathrm{T}_{13}$ —CoHM 5 PE atrazine @ $0.5 \mathrm{~kg} / \mathrm{ha}+\mathrm{HW}+\mathrm{IC}$ & $7.72(57.7)$ & $4.90(22.0)$ & $7.24(50.4)$ & $5.20(25.0)$ \\
\hline $\mathrm{T}_{14}$ - CoHM 5 No WC and no IC & $12.82(162.3)$ & $12.41(152.0)$ & $11.72(135.3)$ & $10.98(118.7)$ \\
\hline SEd & 1.01 & 0.79 & 0.77 & 0.69 \\
\hline $\mathrm{CD}(\mathrm{P}=\mathbf{0 . 0 5})$ & 2.12 & 2.14 & 1.58 & 1.41 \\
\hline
\end{tabular}

Figures in parenthesis are original values; POE—Post emergence application; PE-Pre-emergence; WC-Weed control; IC-Insect control; HW-Hand weeding. 
more competitive for crops than dense weeds with lesser dry matter. Considerable reduction in weed dry weight was recorded with the application of glyphosate at 1800 $\mathrm{g}$ a.e/ha in transgenic $900 \mathrm{M}$ Gold and $3600 \mathrm{~g}$ a.e/ha in transgenic Hishell (0.29 and 1.20) at 40 DAS during kharif 2009 and rabi 2009-2010, respectively (Table 2). This might be due to total weed control as achieved by glyphosate. The findings are in accordance with that post emergence application of glyphosate, following pre emergence herbicides, or three applications of post emergence glyphosate only without pre emergence herbicides reduced total weed dry weight by at least 97 percent when compared to without glyphosate applied plots [8]. Total weed dry weight was effectively reduced in non-transgenic hybrids with pre emergence application of atrazine at $0.5 \mathrm{~kg} /$ ha followed by HW. The dry weight of weeds exhibited an increasing trend from crop germination to harvest in unweeded checks. It might be due to early germination, establishment and quick growth of weeds than crop.

\subsection{Weed Control Efficiency}

During kharif 2009, higher weed control efficiency of 86.42 percent was recorded with the application of atrazine at $0.5 \mathrm{~kg} / \mathrm{ha}$ followed by $\mathrm{HW}$ under $\mathrm{CoHM} 5$ maize hybrid, followed by other non-transgenic hybrids viz., Hishell (83.63), Proagro (83.49) and $900 \mathrm{M}$ Gold (83.18) with same treatment at 20 DAS. Whereas at 40 DAS, transgenic $900 \mathrm{M}$ Gold maize hybrid applied with post emergence glyphosate at $3600 \mathrm{~g}$ a.e/ha recorded maximum weed control efficiency (99.68 percent), followed by same dose of glyphosate under transgenic Hishell (99.40 percent). Whereas during Rabi, 2009-2010, Pre-emergence application of atrazine at $0.5 \mathrm{~kg} / \mathrm{ha}$ followed by HW recorded higher weed control efficiency of 81.21 percent in non-transgenic $900 \mathrm{M}$ Gold maize hybrid. This was followed by other non-transgenic hybrids viz., Hishell, CoHM 5 and Proagro with same treatment at 20 DAS. At 40 DAS, transgenic $900 \mathrm{M}$ Gold applied with glyphosate as post emergence at $3600 \mathrm{~g}$ a.e/ha recorded maximum weed control efficiency ( 98.51 percent), followed by same dose of glyphosate under transgenic Hishell (98.21 percent). Among non-transgenic hybrids with weed control practices, Proagro recorded maximum WCE of 70.62 percent (Table 3). The findings are in line with that two sequential post applications of glyphosate in maize provided up to 92 percent control of ivyleafmorningglory (Ipomoea spp.) as compared to the variable

Table 2. Effect of weed management methods on total weed dry weight in transgenic and non-transgenic maize.

\begin{tabular}{|c|c|c|c|c|}
\hline \multirow{3}{*}{ Treatments } & \multicolumn{4}{|c|}{ Total weed dry weight $\left(\mathrm{g} \cdot \mathrm{m}^{-2}\right)$} \\
\hline & \multicolumn{2}{|c|}{ Kharif 2009} & \multicolumn{2}{|c|}{ Rabi 2009-2010 } \\
\hline & 40 DAS & 65 DAS & 40 DAS & 65 DAS \\
\hline $\mathrm{T}_{1}$-Transgenic Hishell POE glyphosate @ $900 \mathrm{~g} / \mathrm{ha}$ & $2.10(2.40)$ & $2.67(5.11)$ & $3.01(7.09)$ & $3.13(7.77)$ \\
\hline $\mathrm{T}_{2}$-Transgenic Hishell POE glyphosate @ $1800 \mathrm{~g} / \mathrm{ha}$ & $1.76(1.10)$ & $2.32(3.37)$ & $2.35(3.51)$ & $2.13(2.52)$ \\
\hline $\mathrm{T}_{3}$-Transgenic Hishell POE glyphosate @ $3600 \mathrm{~g} / \mathrm{ha}$ & $1.62(0.62)$ & $1.90(1.62)$ & $1.79(1.20)$ & $1.79(1.21)$ \\
\hline $\mathrm{T}_{4}$-Transgenic $900 \mathrm{M}$ Gold POE glyphosate @ $900 \mathrm{~g} / \mathrm{ha}$ & $2.23(2.98)$ & $2.95(6.68)$ & $3.26(8.66)$ & $3.06(7.34)$ \\
\hline $\mathrm{T}_{5}$ —Transgenic $900 \mathrm{M}$ Gold POE glyphosate @ $1800 \mathrm{~g} / \mathrm{ha}$ & $1.51(0.29)$ & $2.48(4.17)$ & $2.29(3.25)$ & $2.21(2.89)$ \\
\hline $\mathrm{T}_{6}$ —Transgenic 900 M Gold POE glyphosate @ $3600 \mathrm{~g} / \mathrm{ha}$ & $1.53(0.33)$ & $1.85(1.41)$ & $1.82(1.32)$ & $1.62(0.64)$ \\
\hline $\mathrm{T}_{7}$ —Hishell PE atrazine @ $0.5 \mathrm{~kg} / \mathrm{ha}+\mathrm{HW}+\mathrm{IC}$ & $5.06(23.61)$ & $3.49(10.21)$ & $5.39(27.06)$ & $3.71(11.74)$ \\
\hline $\mathrm{T}_{8}-$ Hishell No WC and no IC & $10.07(99.43)$ & $9.87(95.49)$ & $8.80(75.43)$ & $9.40(86.32)$ \\
\hline $\mathrm{T}_{9}$ 900MGoldPE atrazine @ $0.5 \mathrm{~kg} / \mathrm{ha}+\mathrm{HW}+\mathrm{IC}$ & $5.33(26.45)$ & $3.60(10.93)$ & $5.29(26.01)$ & $3.98(13.81)$ \\
\hline $\mathrm{T}_{10}-900 \mathrm{M}$ Gold No WC and no IC & $9.69(91.92)$ & $9.94(96.78)$ & $9.43(86.89)$ & $9.36(85.64)$ \\
\hline $\mathrm{T}_{11}$ Proagro PE atrazine $0.5 @ \mathrm{~kg} / \mathrm{ha}+\mathrm{HW}+\mathrm{IC}$ & $5.24(25.45)$ & $3.72(11.87)$ & $5.29(26.00)$ & $4.21(15.70)$ \\
\hline $\mathrm{T}_{12}$-Proagro 4640 No WC and no IC & $9.51(88.42)$ & $9.78(93.72)$ & $9.09(80.58)$ & $9.33(85.12)$ \\
\hline $\mathrm{T}_{13}$ _CoHM 5 PE atrazine @ $0.5 \mathrm{~kg} / \mathrm{ha}+\mathrm{HW}+\mathrm{IC}$ & $5.35(26.67)$ & $3.63(11.18)$ & $5.34(26.50)$ & $4.01(14.10)$ \\
\hline $\mathrm{T}_{14}-\mathrm{CoHM} 5 \mathrm{No} \mathrm{WC}$ and no IC & $10.29(103.95)$ & $10.31(104.23)$ & $9.51(88.50)$ & $9.71(92.32)$ \\
\hline SEd & 0.69 & 0.68 & 0.60 & 0.56 \\
\hline CD $\quad(P=0.05)$ & 1.42 & 1.44 & 1.49 & 1.00 \\
\hline
\end{tabular}

Figures in parenthesis are original values; POE—Post emergence application; PE—Pre-emergence; WC-Weed control; IC-Insect control; HW-Hand weeding. 
Table 3. Effect of weed management methods on weed control efficiency and yield in transgenic and non-transgenic maize.

\begin{tabular}{|c|c|c|c|c|c|c|}
\hline \multirow{3}{*}{ Treatments } & \multicolumn{4}{|c|}{ Weed control efficiency $(\%)$} & \multicolumn{2}{|c|}{ Yield (t/ha) } \\
\hline & \multicolumn{2}{|c|}{ Kharif 2009} & \multicolumn{2}{|c|}{ Rabi 2009-2010 } & \multirow{2}{*}{ Kharif 2009} & \multirow{2}{*}{ Rabi 2009-2010 } \\
\hline & 40 DAS & 65 DAS & 40 DAS & 65 DAS & & \\
\hline $\mathrm{T}_{1}$-Transgenic Hishell POE glyphosate @ $900 \mathrm{~g} / \mathrm{ha}$ & 97.69 & 95.10 & 91.99 & 91.58 & 11.19 & 8.96 \\
\hline $\mathrm{T}_{2}$-Transgenic Hishell POE glyphosate @ $1800 \mathrm{~g} / \mathrm{ha}$ & 98.94 & 96.77 & 96.03 & 97.27 & 11.64 & 9.86 \\
\hline $\mathrm{T}_{3}$-Transgenic Hishell POE glyphosate @ $3600 \mathrm{~g} / \mathrm{ha}$ & 99.40 & 98.45 & 98.20 & 98.69 & 11.78 & 10.12 \\
\hline $\mathrm{T}_{4}$-Transgenic $900 \mathrm{M}$ Gold POE glyphosate @ $900 \mathrm{~g} / \mathrm{ha}$ & 97.13 & 93.59 & 90.21 & 92.05 & 11.30 & 9.33 \\
\hline $\mathrm{T}_{5}$-Transgenic $900 \mathrm{M}$ Gold POE glyphosate @ $1800 \mathrm{~g} / \mathrm{ha}$ & 98.72 & 96.00 & 96.33 & 96.87 & 12.01 & 10.00 \\
\hline $\mathrm{T}_{6}$ —Transgenic $900 \mathrm{M}$ Gold POE glyphosate @ $3600 \mathrm{~g} / \mathrm{ha}$ & 99.68 & 98.65 & 98.51 & 99.31 & 11.68 & 9.92 \\
\hline $\mathrm{T}_{7}$ —Hishell PE atrazine $@ 0.5 \mathrm{~kg} / \mathrm{ha}+\mathrm{HW}+\mathrm{IC}$ & 77.29 & 90.20 & 69.42 & 87.28 & 10.52 & 8.89 \\
\hline $\mathrm{T}_{8}$ - Hishell No WC and no IC & - & - & - & - & 7.57 & 6.36 \\
\hline $\mathrm{T}_{9}$ 900MGold PEatrazine@ $0.5 \mathrm{~kg} / \mathrm{ha}+\mathrm{HW}+\mathrm{IC}$ & 74.56 & 89.51 & 70.61 & 85.04 & 10.27 & 9.27 \\
\hline $\mathrm{T}_{10}-900 \mathrm{M}$ Gold No WC and no IC & - & - & - & - & 7.61 & 7.19 \\
\hline $\mathrm{T}_{11}$ Proagro PE atrazine $0.5 @ \mathrm{~kg} / \mathrm{ha}+\mathrm{HW}+\mathrm{IC}$ & 75.52 & 88.61 & 70.62 & 82.99 & 8.00 & 6.95 \\
\hline $\mathrm{T}_{12}$ - Proagro 4640 No WC and no IC & - & - & - & - & 5.98 & 5.62 \\
\hline $\mathrm{T}_{13}$ CoHM 5 PE atrazine $@ 0.5 \mathrm{~kg} / \mathrm{ha}+\mathrm{HW}+\mathrm{IC}$ & 74.34 & 89.27 & 70.06 & 84.73 & 8.04 & 7.15 \\
\hline $\mathrm{T}_{14}-\mathrm{CoHM} 5 \mathrm{No} \mathrm{WC}$ and no IC & - & - & - & - & 6.08 & 5.73 \\
\hline SEd & & & & & 0.72 & 0.84 \\
\hline $\mathrm{CD}(\mathrm{P}=\mathbf{0 . 0 5})$ & & & & & 1.46 & 1.69 \\
\hline
\end{tabular}

Figures in parenthesis are original values; POE—Post emergence application; PE-Pre-emergence; WC-Weed control; IC-Insect control; HW-Hand weeding.

control (27 to 81 percent) provided by soil applied s-triazines [9].

\subsection{Yield}

Weed management practices showed significant variation in grain yields in both transgenic and non-transgenic hybrids during kharif 2009. Among the treatments evaluated, post emergence application of glyphosate at $1800 \mathrm{~g}$ a.e/ha in transgenic $900 \mathrm{M}$ Gold maize hybrid resulted in higher grain yield of $12.01 \mathrm{t} / \mathrm{ha}$. This was 36.64 percent higher than the unweeded check plots of non-transgenic $900 \mathrm{M}$ Gold maize hybrid $\left(\mathrm{T}_{11}\right)$. The yield obtained under glyphosate as post emergence application at $1800 \mathrm{~g}$ a.e/ ha was similar with that obtained under the treatments of post emergence application of glyphosate at different rates in Hishell (11.19 - $11.78 \mathrm{t} / \mathrm{ha})$ and in $900 \mathrm{M}$ Gold at 900 and $3600 \mathrm{~g}$ a.e/ha (11.30 and $11.68 \mathrm{t} / \mathrm{ha})$. This was followed by non-transgenic Hishell and $900 \mathrm{M}$ Gold with pre emergence application of atrazine at $0.5 \mathrm{~kg} / \mathrm{hafol}-$ lowed by HW (10.52 and 10.27 t/ha). Unweeded check plots recorded lesser grain yield. Significant variation in grain yield of transgenic and non-transgenic maize hy- brids was observed due to various weed control practices during rabi, 2009-2010. Post emergence application of glyphosate at 3600 ga.e/ha in transgenic Hishell maize hybrid resulted in higher grain yield of $10.12 \mathrm{t} / \mathrm{ha}$. This was 37.15 percent higher than the unweeded check plots of non-transgenic Hishell maize hybrid. Grain yield under post emergence application of glyphosate at $3600 \mathrm{~g}$ a.e/ha in transgenic Hishell maize hybrid was comparable with POE application of glyphosate at different rates in transgenic $900 \mathrm{M}$ Gold (9.3 - $10.0 \mathrm{t} / \mathrm{ha})$ and in Hishell at $1800 \mathrm{~g}$ a.e/ha (9.86 t/ha) as well in non-transgenic Hishell and $900 \mathrm{M}$ Gold maize hybrids with atrazine at 0.5 kg/hafollowed by HW (8.89 and 9.27 t/ha) (Table 3). Unweeded maize hybrids resulted in lesser grain yield. Chemical weeding at 2 - 3 leaf stage of weeds followed by hand weeding at 50 DAS gave promising results of 34 percent and, 33 percent of increases in grain and stalk yields [10].

\section{Conclusion}

On the basis of the above results, both the transgenic maize hybrids with single application of glyphosate at 2 - 
4 leaf stage of weeds (approximately 25 DAS of transgenic maize hybrids) could provide the season long weed control. Higher grain yield was recorded with POE application of glyphosate at $1800 \mathrm{~g}$ a.e/ha in transgenic 900 $\mathrm{M}$ Gold and $3600 \mathrm{~g}$ a.e/ha in transgenic Hishell during kharif, 2009 and rabi, 2009-2010 seasons, respectively.

\section{Acknowledgements}

The authors thank Monsanto India Pvt. Ltd., Mumbai for financial assistance rendered for carrying out the research work.

\section{REFERENCES}

[1] A. R. Sharma, A. S. Toor and H. S. Sur, "Effect of Interculture Operations and Scheduling of Atrazine Application on Weed Control and Productivity of Rainfed Maize (Zea mays) in Shiwalik Foot Hills of Punjab," Indian Journal of Agricultural Sciences, Vol. 70, No. 11, 2000, pp. 757-761.

[2] P. E. Blanchard and W. W. Donald, "Herbicide Contamination of Groundwater beneath Claypan Soils in NorthCentral Missouri," Journal of Environmental Quality, Vol. 26, 1997, pp. 1613-1621. doi:10.2134/jeq1997.00472425002600060022x

[3] C. L. Main, A. J. Michael and E. C. Murdock, "Weed Response and Tolerance of Enhanced Glyphosate-Resistant Cotton to Glyphosate," Journal of Cotton Science, Vol. 11, No. 2, 2007, pp. 104-109.
[4] K. A. Gomez and A. A. Gomez, "Statistical Procedures for Agricultural Research," Wiley India Pvt. Ltd., New Delhi, 2010.

[5] G. Ramesh and T. Nadanassababady, "Impact of Herbicides on Weeds and Soil Ecosystem of Rainfed Maize (Zea mays)," Indian Journal of Agricultural Research, Vol. 39, No. 1, 2005, pp. 31-36.

[6] C. H. Koger and R. N. Reddy, "Glyphosate Efficacy, Absorption and Translocation in Pitted Moringglory (Ipomoea lacunose)," Weed Science, Vol. 53, No. 3, 2005, pp. 277-283. doi:10.1614/WS-04-098R

[7] S. L. Mundra, A. K. Vyas and P. L. Maliwal, "Effect of Weed and Nutrient Management on Weed Growth and Productivity of Maize (Zea mays L.)," Indian Journal of Weed Science, Vol. 35, No. 1-2, 2003, pp. 57-61.

[8] K. N. Reddy and J. C. Boykin, "Weed Control and Yield Comparisons of Twin and Single-Row Glyphosate Resistant Cotton Production Systems." Weed Technology, Vol. 24, 2010, pp. 95-101. doi:10.1614/WT-D-09-00044.1

[9] J. A. Ferrell and W. W. Witt, "Comparison of Glyphosate with Other Herbicides for Weed Control in Corn (Zea mays): Efficacy and Economics," Weed Technology, Vol. 16, No. 3, 2002, pp. 701-706. doi:10.1614/0890-037X(2002)016[0701:COGWOH]2.0. $\underline{\mathrm{CO} ; 2}$

[10] M. Riaz, M. Jamil and T. Z. Mahmood, "Yield and Yield Components of Maize as Affected by Various Weed Control Methods under Rain-Fed Conditions of Pakistan," International Journal of Agriculture and Biology, Vol. 9, 2007, pp. 152-155. 